\title{
FACTORS DECIDING ON THE ENTERPRISE CONCEPT DEVELOPMENT IN THE PRODUCTION OF PLASTICS
}

\begin{abstract}
In the chapter was presented enterprise dealing with the processing of plastics. Results of the BOST survey were presented from the range of the first principle of Toyota. It was made analysis of respondents' characteristics. A structure of assessments was determined and correlation graphs were built.
\end{abstract}

Key words: toyotarity, the BOST method, plastics, improvement

\section{Characteristics of the researched enterprise}

Researched enterprise is a company acting from 1985 on the printing market and from 2003 also in the business of the processing of plastics. The company from many years is dealing with the printing and design full service of companies and the institution. The enterprise is dealing mainly with the offset printing, and with screen process. Additional services that an enterprise is dealing with:

- milling of details, assembly holes with the help of the milling CNC plotter,

- ultrasound welding - welding machines,

- the own tool room and conducting projects from the beginning to official certification of details,

- assemblies,

- tests to wishing the customer, production attempts, implementing of new raw materials.

\footnotetext{
${ }^{1}$ mgr inż., Czestochowa University of Technology, Faculty of Management, Institute of Production Engineering: mielczarek@ zim.pcz.pl,

${ }^{2}$ mgr inż., Czestochowa University of Technology, Faculty of Management, Institute of Production Engineering: k.knop@poczta.fm
} 
Additionally the company offers also varnishing details and the overprint on metalized details. It guarantees also appropriate brightening of copied samples of colours. It is possible to make the wide range of the graphical cover of products from standard to 3D. At first the company was one-man business dealing with making advertisements, shop signs, the visual setting of exhibitions and occasional parties. Then a silk-screen printing was started. making inscriptions on fabrics (t-shirt, working clothes, and the haberdashery). In 1990 an offset printing house dealing mainly with the production of cardboard containers for producers of the footwear was started. It filled the lack of the service of this type on the local market. Ten years later it was started production of colour pattern books of paints, plaster and fugues for producers of building chemistry. The company based on the own technology of productions and the knowhow. A company restructuring and a change of the range of production that consisted in starting the printing on plastics with technique of the screen-screen printing and for concerns of household equipment. Next was started the Department of the Processing of Plastics and directing the company on the comprehensive and specialist production for recipients of the household equipment branch. A modern technology of the UV screens printing, enabling to make multicoloured graphical applications on elastic retails, mainly on the control panels. The company is still developing, signing new contracts with customers of the home appliances business as automobile industry.

Taking into consideration the cooperation of the enterprise with producers of the household appliance and the automotive business the company still is developing the production of details with method of the injection and also inscription on plastic parts. The enterprise makes the inscription on details of different plastics, such as: ABS, PVC, PC, PS, $\mathrm{PP}, \mathrm{PE}$, with technique of silk-screen printing. These are most often elastic retails for home appliances producers, for example control panels and hand wheel for washing machines, dishwashers, clothes driers, cookers and for the automotive industry. Over 20 year experience allows the company for implementing the inscription on the most complicated 
details in terms of shape and used materials. Patterns are basic commodities of the printing house which are made in different variants. A possibility of applying different dimensions and amounts of colours exist on individual leaflets with colour models.

\section{The methodology of researches and statistical characteristics of results}

BOST is survey where the questions are so well-matched as to judge enterprise and its immaterial stores are possible. In the purpose to form an opinion it is essential to know the opinion of workers from different ranks in enterprise (BORKOWSKI S. 2012A). It was made on the base of 14 principles of the Toyota (LIKER J.K. 2005). It lets on better look on the enterprise by eyes of workers. (BORKOWSKI S. 2012B).

In order to the identification the factors that decide about the conception of the enterprise development some workers filled a BOST questionnaire. They expressed their opinions on this topic and different problems in researched enterprise.

Respondents were asked to answer the following question: What factors decide the development concept of your company?

They judged 7 factors using a scale from 1 to 7 , where 1 means the least essential element, and 7 - the most important element. The person who is filling questionnaire is judging the following factors (BORKOWSKI S. 2012C):

\begin{tabular}{|c|c|}
\hline DK & Customer's interest \\
\hline IP & Product innovation \\
\hline WK & Cooperation with partners \\
\hline $\mathrm{ZP}$ & Confidence in relations with employees \\
\hline $\mathrm{SP}$ & Independence and responsibility of employees \\
\hline RT & Development of technology \\
\hline PR & Company culture care \\
\hline
\end{tabular}


This set of factors describing the first Toyota management principle will be called factors of area E2. Table1 presents the percentage share of the importance assessments of the factors belonging to area E2.

Table 1. Structure [\%] of importance ratings for factors of E2 area

\begin{tabular}{|c|c|c|c|c|c|c|c|}
\hline \multirow{2}{*}{ Evaluation } & \multicolumn{7}{|c|}{ Factors indicating } \\
\cline { 2 - 8 } & DK & IP & WK & ZP & SP & RT & PR \\
\hline 1 & 0,0 & 0,0 & 6,7 & 40,0 & 0,0 & 6,7 & 46,7 \\
\hline 2 & 0,0 & 13,3 & 20,0 & 20,0 & 13,3 & 6,7 & 26,7 \\
\hline 3 & 6,7 & 33,3 & 6,7 & 6,7 & 26,7 & 20,0 & 0,0 \\
\hline 4 & 0,0 & 13,3 & 26,7 & 13,3 & 13,3 & 20,0 & 13,3 \\
\hline 5 & 40,0 & 20,0 & 20,0 & 0,0 & 6,7 & 6,7 & 6,7 \\
\hline 6 & 6,7 & 13,3 & 6,7 & 13,3 & 13,3 & 40,0 & 6,7 \\
\hline 7 & 46,7 & 6,7 & 13,3 & 6,7 & 26,7 & 0,0 & 0,0 \\
\hline
\end{tabular}

Source: own study

The significance of strategic factors in these enterprises was depicted with the use of circle graphs presented in Fig. 1.
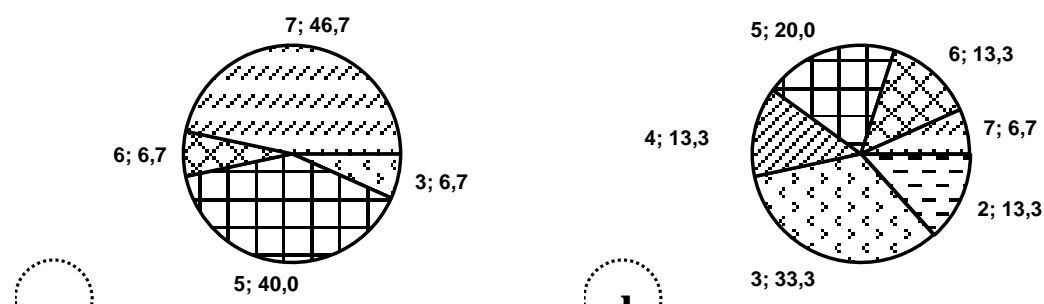

a

b. 

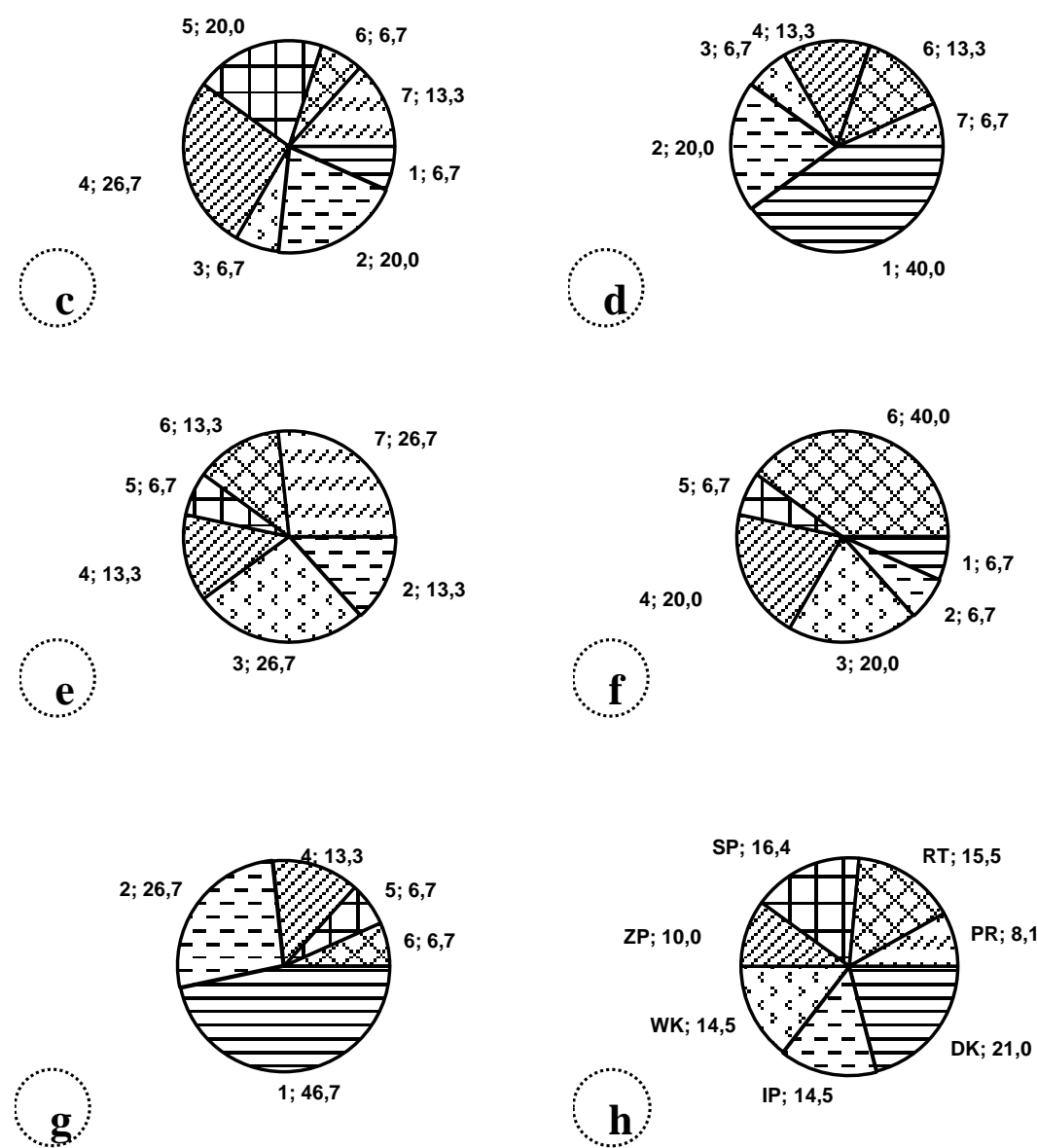

Fig.1. Circular graphs - structure of ratings for factors in E2 area: a) DK, b) $I P, c) W K, d) Z P, e) S P, f) R T, g) P R, h)$ average.

The interpretation of the graphic presentation of survey results allows drawing a clear conclusion which factors are the most important. Analyzing Fig. 12h it was affirmed that customer interest (DK), 
independence and responsibility of employees (SP) and development of technology (RT) received the highest average.

On the basis of results it was made comparing the following statistical indicators: average, the variance, the standard deviation, the coefficient of variation, skewness and excess coefficient for factors in E2 area (BORKOWSKI S., KNOP K., BARTCZAK M. 2011). Graphical interpretation of these indicators was presented in Fig. 2.

Averages presented in Fig 2a and the maximum value was calculated for the factor customer's interest (DK) on the level 5.87. The lowest average was for the factor company culture care (PR) on the level 2.27. Standard deviation (Fig. 2b) there is in range 1,25 - 2.11, and Qx deviation (Fig. $2 \mathrm{c}$ ) in the range $2.00-3.50$.

In order to assess factors with the use of variation coefficient it is necessary to prepare the following statement (PUŁASKA-TURYN B. 2008): $0-20 \%$ - weak variation of feature, $20-40 \%$ - moderate variation of feature, $40-60 \%$ - strong variation of feature, $60 \%$ and more - very strong variation of feature.

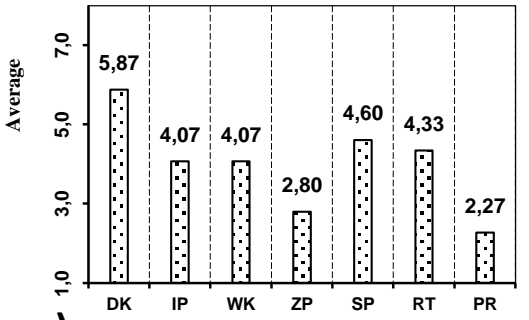

a)

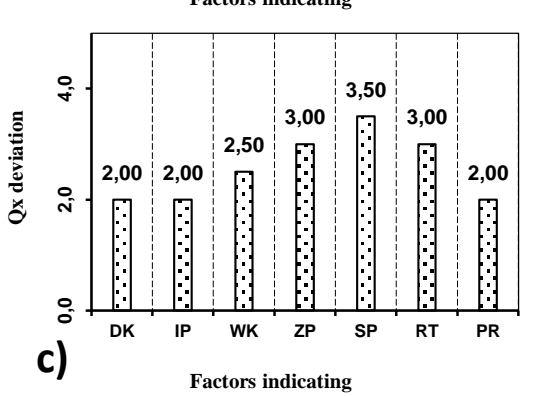

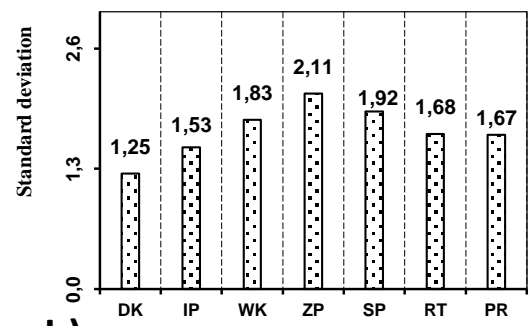

b)

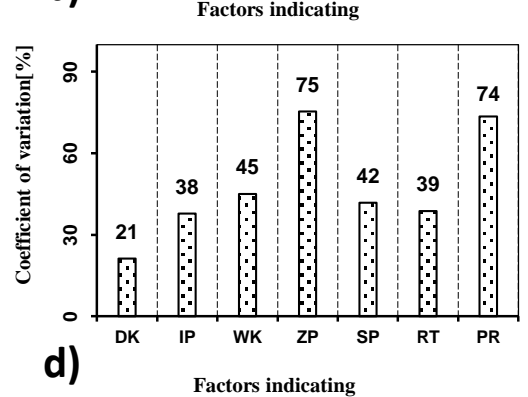



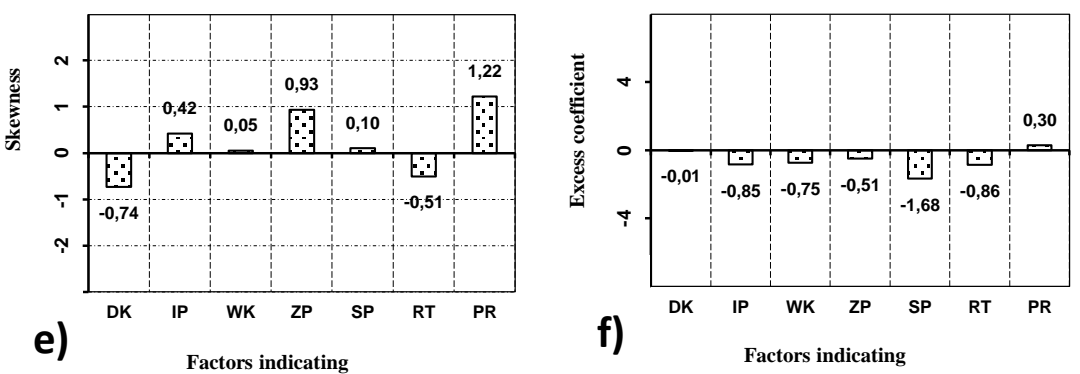

Fig. 2. Comparison: a) average, b) standard deviation, c) $Q_{x}$ deviation, $d$ ) coefficient of variation, $e$ ) skewness, $f$ ) excess coefficient for E2 area factors.

Source. own study

Coefficients of variation presented in Fig. $2 d$ show a very strong variation of factors: confidence with relations with employees (SP) and company culture care (PR).

The measurement of skewness is (Fig. 2e) a classic coefficient of asymmetry $(0.0$ - 0.4$)$ - very weak distribution asymmetry, $(0.4-0.8)$ weak distribution asymmetry, $(0.8$ - 1.2) - moderate distribution asymmetry $(1.2$ - 1.6) - strong distribution asymmetry, (more than $1.6-$ very strong distribution asymmetry). The distribution of rates for company culture care (PR) indicate strong positive skewness.

For appropriate interpretation of results the following statement is necessary: We $<0$ - distribution is characterized by lower than standard peakedness, $\mathrm{We}=0$ distribution is characterized by standard peakedness, We $>0-$ distribution is characterized by peakedness higher than standard. For five factors the distribution of rates is characterized by lover than standard peakedness.

\section{Significance sequences deciding on the development of the enterprise}

On the basis of numerical data and percentage structure of significance rates assigned to factors belonging to area E2 the Pareto- 
Lorenz diagrams have also been created and presented in Fig. 3. This chart shows, in descending order, relative share of each element in the overall effect. This method has been applied to demonstrate the participation of each element in the discussed area, and then to arrange all elements according to their level of significance (SYGUT P. 2014).

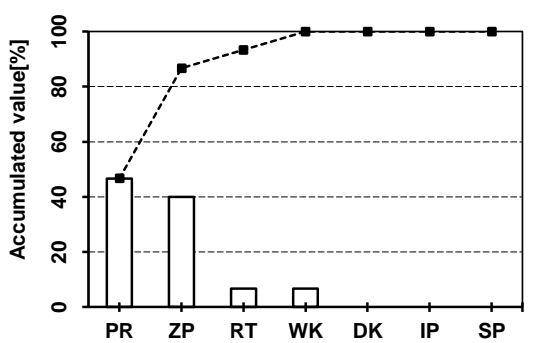

a)
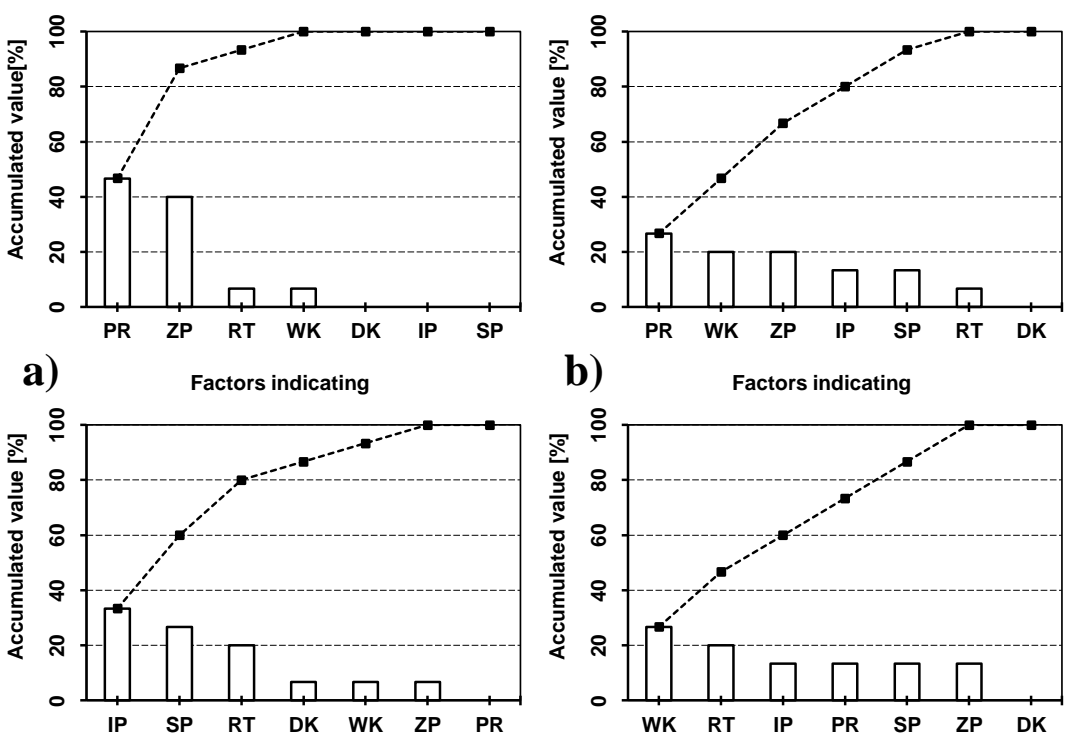

b)

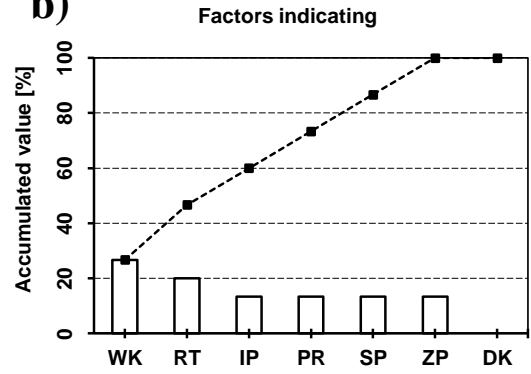

c)

d)
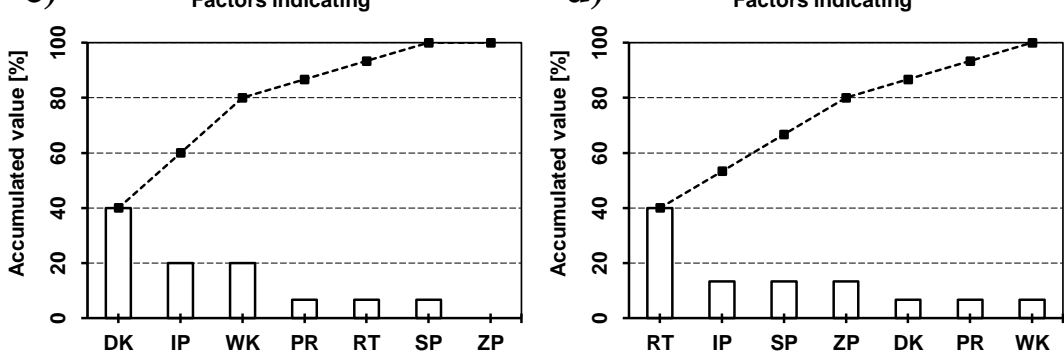

e)

Factors indicating

f)

Factors indicating 


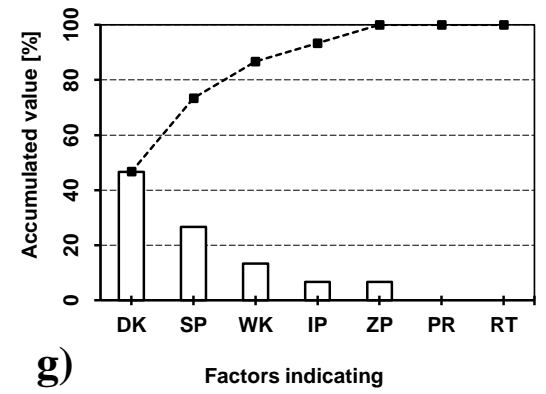

Fig. 3. Pareto-Lorenz Diagrams importance factors $\mathrm{E} 2$ area for evaluations: a) "1", b) "2", c) "3", d) "4" e) "5", f) "6", g) "7".

Source: own study

Each of diagrams is presenting accumulated value of individual assessments from „1" to „7”. As a result of tests the following significance sequences have been determined:

$$
\begin{aligned}
& \text { Evaluation , } 1 \text { ” PR }>\text { ZP }>(\text { RT, WK })>(\mathrm{DK}, \mathrm{IP}, \mathrm{SP}) \\
& \text { Evaluation „2" } \mathrm{PR}>(\mathrm{WK}, \mathrm{ZP})>(\mathrm{IP}, \mathrm{SP})>\mathrm{RT}>\mathrm{DK} \\
& \text { Evaluation ,3" IP }>\text { SP }>\text { RT }>(D K, W K, Z P)>P R \quad \text { (3) } \\
& \text { Evaluation „4" WK }>\text { RT }>(\text { IP, } \mathrm{PR}, \mathrm{SP}, \mathrm{ZP})>\mathrm{DK} \\
& \text { Evaluation ,5" DK > (IP, WK })>(\text { PR, RT, SP })>\text { ZP } \\
& \text { Evaluation ,6” RT > (IP, SP, ZP) }>(\text { DK, PR, WK }) \\
& \text { Evaluation ,7” DK > SP > WK > (IP, ZP) > (PR, RT) }
\end{aligned}
$$

Analysing fig. 3a and formula 12.1 which concerned the evaluation "1" we noticed that according to respondents a factor company culture care (PR) is the least important factor. Fig. 3g and formula 12.7 is showing number of the importance of factors for the highest evaluation „7". Definitely a factor customer's interest (DK) received the highest evaluations. Two factors culture care (PR) and development of technology (RT) not received any the highest evaluations.

\section{Correlation graphs}

In the analyzed enterprises the influence of respondents' characteristic features on the significance of individual factors was defined with use of the correlation analysis (PUŁASKA-TURYNA B. 2008). Respondents differ in terms of their personal features: gender, education, 
age, work experience, mobility, way of employment (BORKOWSKI, S., Sygut, P., JAGUSIAK-KocIK, M). The significance of correlation was tested for $\alpha=0,05, \alpha=0,1$ and $\alpha=0,2$. A graphic interpretation of this analysis is presented in Fig. 4.
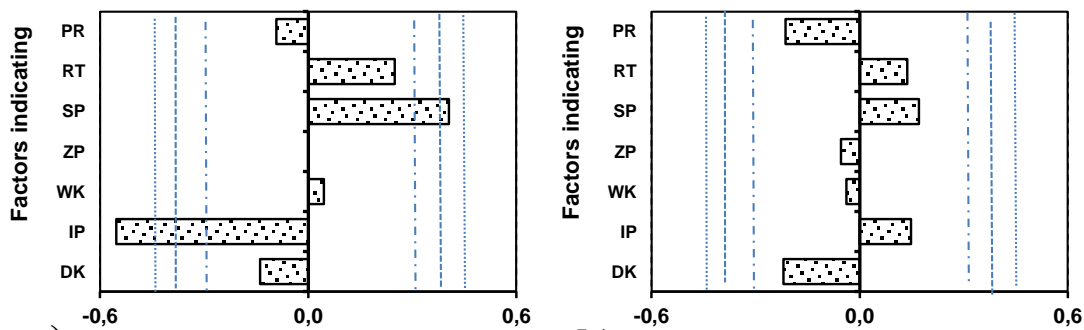

a)

Correlation coefficient

b)

Correlation coefficient
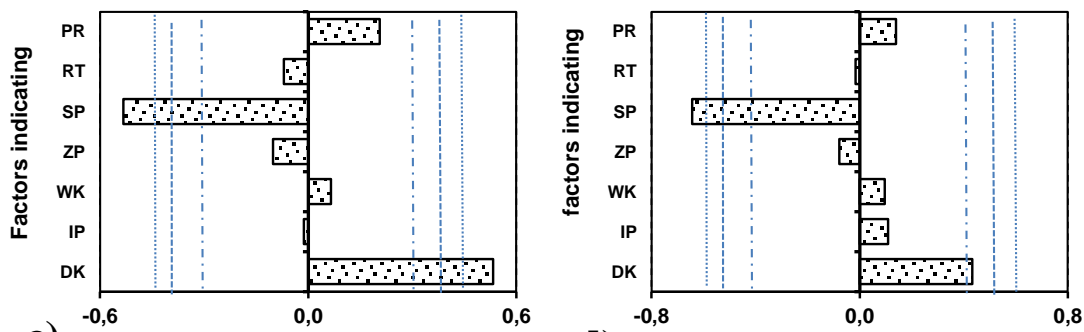

c)

Correlation coefficient

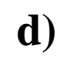

Correlation coefficient

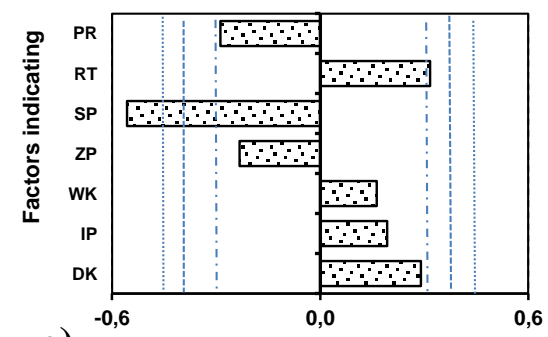

e)

Correlation coefficient

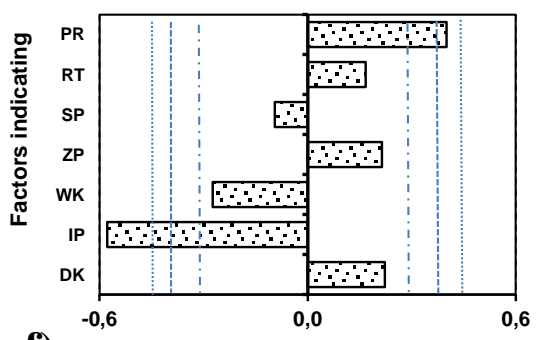

f)

Correlation coefficient

4. Correlation graphs for factors in E2 area depending on the respondents, features: a) gender, b) education, c) age, d) work experience, e) mobility, f) way of recruitment $\alpha=0,2$ (internal lines), $\alpha=0,1$ (central lines), $\alpha=0,05$ (external lines).

Source: own study 
In Fig. 4a shows correlation between respondent's gender and selected by them significance rates for factors describing the first Toyota's management principle. It can be noticed that statistically only in case of one element a significant correlation has occurred for factor product innovation (IP) on three $\alpha$ level.

Fig. $4 \mathrm{~b}$ is presenting correlation between the education and with evaluations of the importance factors.

Fig. 4c shows that significance rates of only two factor Independence and responsibility of employees (SP) negative correlations and - customer's interest (DK) positive correlation.

Fig. $4 \mathrm{~d}$ is presenting correlation between work experience and with evaluations of the importance factors. Strong negative correlations are only for independence and responsibility of employees (SP) factors. For mobility (Fig. 4e) situation is similar - strong negative correlations is only for independence and responsibility of employees (SP) factors for every level $\alpha$.

Last Fig. $4 \mathrm{f}$ is presenting the relation for way of recruitment. Strong negative correlations are only for product innovation (IP) factors for every level $\alpha$.

\section{Summary}

The starting point for changes (improvement) is recording the existing condition. Tests were carried out in the enterprise producing various goods of plastics. Employees were asked to give their opinions on the present condition of the company and to express their opinions concerning strategic development factors contained in the description of the first Toyota management principle. During the analysis of the results from area E2 of the BOST survey it can be noted that the most important factor for the employee is customer's interests (DK) achieved by delivery of high quality products and services, which meet customer's needs and ensure achievement of the greatest possible satisfaction. The results of 
research concerning characteristic features of statistical groups of rates, their structure, significance sequences for separate rates can be a great support in making a strategic decision in the company.

\section{Bibliogrphy}

1. BORKOWSKI S. 2012a. Dokumenty zawierajace wymyślony termin (TOYOTARYZM) oraz zawierajace nazwe i strukturę opracowanej metody (BOST). Potwierdzenie daty. „AAK” KANCELARIA PATENTOWA. s.c. Częstochowa.

2. BORKOWSKI S. 2012b. Zasady zarządzania Toyoty w pytaniach. Wyniki badań BOST. Wydawnictwo PTM. Warszawa.

3. BORKOWSKI S. 2012c. Toyotaryzm. Wyniki badań BOST. Wydawnictwo PTM. Warszawa.

4. BORKOWSKI, S. 2013. Prezentacja wyników analizy korelacyjnej $w$ metodzie BOST. Ocena funkcjonowania organizacji w oparciu o zasady Toyoty. Borkowski S. (Ed.). Częstochowa: Oficyna Wydawnicza Stowarzyszenia Menedżerów Jakości i Produkcji (SMJiP),

5. Borkowski, S., SYgut, P., JAGUSIAK-KociK, M. 14 Toyota's Management Principle Basis of Process Improvement in the Baking Industry. Toyotarity. Improvement of Production/Service Processes. Monography. Borkowski S., Sygut P. (Ed.). Celje: Faculty of Logistics, University of Maribor, 2012.

6. LIKER J.K. 2005. Droga Toyoty: 14 zasad zarzadzania wiodacej firmy produkcyjnej świata. Wydaw. MT Biznes, Warszawa.

7. PuŁaska-Turyna B. 2008. Statystyka dla ekonomistów. Wydanie II rozszerzone. Difin. Warszawa.

8. SyGuT P. 2014. Wykorzystanie czynników zasady 1 zarzadzania Toyoty do oceny procesu malowania proszkowego. Rozdziat 8. [W] BORKOWSKI S., SyGuT P. (red). Toyotaryzm. Znaczenie innowacji $w$ metodzie BOST. Oficyna Wydawnicza Stowarzyszenia Menedżerów Jakości i Produkcji. Częstochowa. 